Prace Komisji Geografii Komunikacji PTG Transport Geography Papers of Polish Geographical Society

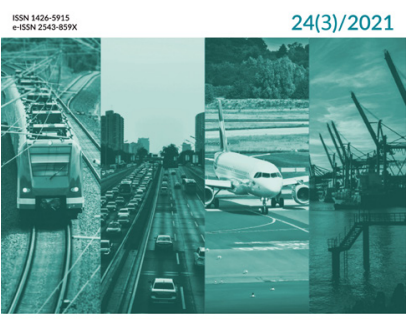

\section{Prace Komisji Geografii Komunikacji PTG}

2021, 24(3), 19-35

DOI 10.4467/2543859XPKG.21.016.15043
Otrzymano (Received): 23.07.2021

Otrzymano poprawioną wersję (Received in revised form): 20.08.2021

Zaakceptowano (Accepted): 20.08.2021

Opublikowano (Published): 30.09.2021

\title{
DOSTĘPNOŚĆ TRANSPORTOWA WYBRANYCH OŚRODKÓW MIEJSKICH POMORZA ŚRODKOWEGO Z UWZGLĘDNIENIEM ZJAWISKA WYKLUCZENIA KOMUNIKACYJNEGO
}

\section{Transport accessibility of selected towns in the Middle Pomerania region including the phenomenon of the transport exclusion}

\author{
Adam R. Parol \\ Instytut Geografii i Gospodarki Przestrzennej, Uniwersytet Jagielloński, Gronostajowa 7, 30-387 Kraków \\ e-mail: ar.parol@student.uj.edu.pl
}

https://orcid.org/0000-0002-4969-4571

Cytacja:

Parol A. R., 2021, Dostępność transportowa wybranych ośrodków miejskich Pomorza Środkowego z uwzględnieniem zjawiska wykluczenia komunikacyjnego, Prace Komisji Geografii Komunikacji PTG, 24(3), 19-35.

Streszczenie:W artykule podjęto tematykę dostępności komunikacyjnej ośrodków władzy powiatowej bądź im równoważnych z poziomu miejscowości będących siedzibami urzędu gminy. Obszarem badań było Pomorze Środkowe. Wskazano obszary o różnym stopniu rozwinięcia oferty przewozowej między branymi pod uwagę ośrodkami w kontekście zgodności rzeczywistych ciążeń komunikacyjnych z istniejącym podziałem administracyjnym na poziomie powiatowym, jak również w celu wskazania obszarów wykluczonych transportowo. Odniesiono się do roli miast w sieci osadniczej jako ośrodków oferujących konkretne dobra i usługi, do których lokalna społeczność udaje się celem nabycia, nie zamykając się jednocześnie w ramach istniejącego podziału administracyjnego. Na potrzeby opracowania skonstruowano wskaźniki powiązań komunikacyjnych oraz rangi miast. Rezultaty postępowania badawczego okazały się być zgodne ze sformułowaniami zawartymi w innych opracowaniach naukowych podejmujących tę tematykę, choć były one bardziej dokładne i aktualne. Zawarte w artykule wnioski, szczególnie dotyczące korekt w podziale terytorialnym w celu dopasowania jego granic do rzeczywistych powiązań, mogą pełnić rolę sugestii dla decydentów w zakresie kształtowania polityki transportowej w regionie oraz dla osób odpowiedzialnych za przestrzenny wymiar administracji państwowej.

Słowa kluczowe: Pomorze Środkowe, transport, komunikacja, wykluczenie, transport publiczny

\begin{abstract}
This article brings up the issue of the transport accessibility of the capital cities or their equivalents on the county level. The Middle Pomerania region was taken as a research area. Some of these regions were pointed as to show the different level of the transport offer. The aim was to present the context of compatibility between functional linkages and existing administrative division on the county level, but also to find areas excluded in public transport system. The role of the towns in the settlement system was referred to places that offer selected goods and services which local community needs and have to travel in order to acquire them, with no-closing within the framework of the existing administrative division. For the purposes of the article the indicators of communication linkages and town ranks were constructed. The results of the research procedure turned out to be compatible with the wordings contained in other scientific studies dealing with this topic, but they were taken more precisely and up-to-date. Conclusions contained in this paper, especially regarding corrections in the territorial division to adjust its borders to actual linkages, may be used as a suggestions for people responsible for moulding transport policy in the region and for spatial dimension of state administration.
\end{abstract}

Keywords: Middle Pomerania, transport, communication, exclusion, public transport 


\section{Wstęp}

Niniejszy artykuł podejmuje tematykę dostępności transportowej ośrodków władzy powiatowej oraz miast wyposażonych w podstawowe dobra i usługi, ze zwróceniem uwagi na zjawisko wykluczenia transportowego. Jako że jest to zagadnienie często pojawiające się w debacie publicznej, nie tylko w środowisku naukowym, opracowanie ma charakter diagnostyczny, wskazujący na rzeczywisty wymiar tego zjawiska. Szczególnie ciekawym dla tego rodzaju badań jest obszar Pomorza Środkowego - przestrzeni wykluczonej w obecnym podziale administracyjnym na różnych płaszczyznach. Podjęcie wyżej zarysowanej tematyki ma na celu wskazanie obszarów, w których codzienne funkcjonowanie związane z rutynowymi przemieszczeniami w celu nabycia pewnych dóbr lub usług jest zaburzone ze względu na zaniedbania w zakresie oferty przewozowej między miejscowościami będącymi siedzibami urzędów gmin a najbliższymi rozwiniętymi ośrodkami obsługującymi lokalne zaplecze.

\section{Dostępność transportowa w badaniach geograficznych}

Niejednorodność przestrzeni geograficznej, tak w wymiarze przyrodniczym, jak i antropogenicznym, oraz ograniczenia związane ze stopniem rozwoju społeczeństwa i jego wytworów, są bezpośrednio powiązane z nierównomiernym oraz najczęściej nieodpowiadającym zapotrzebowaniu dostępem do dóbr, usług i innych funkcji niezbędnych do zaspokojenia potrzeb danej społeczności, stanowiąc istotny składnik poziomu i jakości życia oraz atrakcyjności inwestycyjnej (Taylor, 1999; Guzik i in., 2020). W sposób analogiczny, a więc nierównomierny, i w wyniku oddziaływania wielu czynników kształtuje się sieć osadnicza. Wynikającą z tego tytułu konieczność odbycia podróży w celu zrealizowania potrzeb życiowych (niezależnie od stopnia ich priorytetowości dla danej osoby lub grupy ludzi), na podstawie istniejących możliwości wykonania takiego przemieszczenia, określa się mianem dostępności. Schematyczny związek dostępności i przestrzeni przedstawia ryc. 1. W niniejszym opracowaniu przedmiotem badań jest ogniwo łączące lewą i prawą stronę schematu, co jest podejściem adekwatnym dla analiz transportowych. Cechy jednostki bądź grupy społecznej interesują najczęściej badaczy społecznych, a rodzaj działalności i funkcji, która jest motywacją do potencjalnego odbycia przemieszczenia - naukowców w nurcie ekonomicznym (Taylor, 1999).

Z. Taylor (1999) zauważa, że „w literaturze geograficznej i ekonomicznej pojęcie dostępności odnosi się zwykle do koncepcji bliskości, łatwości przestrzennej interakcji lub potencjalnych kontaktów w funkcjami". Pogląd ten, ukształtowany w II połowie XX w., jest wynikiem badań R. D. Ingrama, który wprowadził pojęcia dostępności względnej oraz dostępności całkowitej, jak również W. L. Garrisona, który rozwinął koncepcje związane z wykorzystaniem metod grafowych i modeli grawitacyjnych (Taylor, 1999). Na tej podstawie badacze dostępności w ujęciu transportowym rozwinęli koncepcje modeli potencjału demograficznego, z uwzględnieniem m.in. miejsca pracy czy lokalizacji usług, w celu zdefiniowania oddziaływań między ośrodkami. Najczęstszym sposobem przemieszczenia, który w tego rodzaju badaniach stanowił ich podstawę, była podróż transportem publicznym z punktu A do punktu B. Na tej podstawie zaczęto formułować opisy dostępności ośrodków oraz poszczególnych funkcji, które pełnią takie obiekty jak placówki handlowe, edukacyjne czy zakłady pracy (Taylor, 1999). Taka orientacja badawcza została zastosowana przez autora niniejszego artykułu. Całość teoretycznych i rzeczywistych przemieszczeń z użyciem zorganizowanych środków transportu tworzy sieć transportową (Kwarciński, Załoga, 2019).

Jedną z pionierek polskich analiz poruszających tematykę hierarchii ośrodków w sieci osadniczej oraz rozkładów odległości dojazdów do nich była A. Potrykowska (Taylor, 1999). A. Grzelakowski wyróżnił natomiast fizyczną oraz realną dostępność transportową, z których pierwsza jest związana z przemieszczeniami przy użyciu istniejącej infrastruktury transportowej, druga natomiast - z rodzajem i jakością oferowanych połączeń (Kwarciński, Załoga, 2019). Cechą wyróżniającą polskie badania nad dostępnością, szczególnie w II połowie XX w., stanowi niewielka liczba opracowań dotyczących przejazdów dobrowolnych, a w konsekwencji - nacisk na teoretyczną dostępność, nie zaś na rzeczywiste przemieszczenia (Taylor, 1999; Guzik, 2003).
Jednostka
lub grupa
społeczna)
Połączenie (środki transportu i łączności)

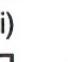

Działalność (funkcja), do której potrzebujemy dostępu

Ryc. 1. Schematyczne przedstawienie dostępności w ujęciu przestrzennym. 
W badaniach nad dostępnością wyróżnić można również nurty odnoszące się do sposobności przestrzennej, czyli czasu, który należy przeznaczyć na przemieszczenie $w$ dowolnym momencie linii czasu, jak również do przewozów (wyniku spożytkowanego potencjału dostępności), ruchliwości (fizycznego przemieszczenia), dostępności osobistej oraz mobilności (Taylor, 1999).

W artykule posłużono się pojęciem dostępności transportowej określonej za pomocą jednostek czasu. $\mathrm{Na}$ jego definicję składają się koncepcje dostępności czasowej i przestrzennej (pokonanie odległości w określonym czasie) oraz dostępności komunikacyjnej wraz z uwzględnieniem sieci komunikacyjnej danego obszaru (Guzik, 2003). Określono w ten sposób punkty, dla których dostępność jest badana (miejsca rozpoczęcia podróży), punkty, dla których jest ona określana (cele podróży), oraz sposoby pokonania przestrzeni (transport publiczny).Zastosowana metodyka została szczegółowo opisana w części "Materiały źródłowe i metody analizy".

Badania nad dostępnością dotykają niejednokrotnie problemu wykluczenia transportowego, choć w polskich badaniach nurt ten rozwijany jest powoli (m.in. Goliszek i in., 2017; Ciechański, 2020). Dobra dostępność transportowa wiąże się z wieloma zaletami, takimi jak oszczędność czasowa i finansowa w pokonywaniu odległości czy większe możliwości rozwoju regionalnego z powodu funkcji usługowych, stymulujących, dochodowych i integracyjnych pełnionych przez transport. Niewystarczająca oferta przewozowa, niska jakość infrastruktury transportowej, a nawet jej brak, prowadzą do wykluczenia komunikacyjnego obszaru, na którym te negatywne zjawiska zachodzą, szczególnie, że często występują one jednocześnie. W takich miejscach realizacja podstawowych usług, w tym publicznych, jest utrudniona lub niemożliwa. Szczególnie dotyczy to zmniejszenia bodźców prorozwojowych czy braku odpowiedniego skomunikowania, które to nie są w stanie poprawić tej trudnej sytuacji. Co więcej, obszary o dobrej dostępności i rozwiniętej infrastrukturze komunikacyjnej wykazują wysoki poziom rozwoju gospodarczego, co pogłębia istniejące już wcześniej dysproporcje w przestrzeni, ponieważ miejsca o niezadowalającej sieci drogowej i kolejowej nie są w stanie z nimi konkurować (Guzik (red.), 2012). W ujęciu chorograficznym, wykluczenie transportowe potrafi doprowadzić poszczególne obszary do ich peryferyzacji w układzie przestrzennym, czego skutkiem jest trudność w dostaniu się do pracy, edukacji czy usług wyższego rzędu i/lub zmniejszonymi możliwościami podróży $w$ dni wolne od pracy. W kontekście społecznym ten rodzaj wykluczenia skutkuje obniżoną samooceną mieszkańców takiego obszaru (Trutkowski (red.), 2016), a nawet wykluczeniem społecznym (Schwanen i in., 2015, za: Ciechański, 2020). Końcowym efektem takiego stanu może być odpływ ludności z obszaru peryferyjnego w sieci transportowej, co może wiązać się z kolejnymi cięciami w ofercie przewozowej i spadkiem nakładów inwestycyjnych na infrastrukturę transportową. Jest to zgodne z zasadą tzw. błędnego koła, kiedy to mała podaż powoduje zmniejszenie popytu. Ograniczenia w ofercie dotknęły rynek polskich przewozów kolejowych na przełomie XX i XXI w., wskutek czego łączna długość linii kolejowych w Polsce zmniejszyła się między 1990 a 2019 r. z 26,2 tys. km do 18,5 tys. km (o ok. 30\%). Odcięcie wielu miejscowości od regularnych przewozów pasażerskich pociągami oraz spadek liczby wykonywanych kursów przyczyniły się do zmniejszenia liczby podróżujących koleją w tym okresie o ok. 70\% (z $1 \mathrm{mld}$ do $300 \mathrm{mln}$ podróży kolejowych rocznie) (Trammer, 2019). Podobne procesy miały miejsce w sferze przewozów autobusowych - w latach 1990-2015 praca przewozowa tej części rynku transportowego spadła o 54\%, a liczba pasażerów - o 80\% (Rosik i in., 2017).

Należy dodać, iż pewnym wymiarem wykluczenia transportowego (oraz powodem problemów z rzetelnością wykonanych badań naukowych) jest trudność w dotarciu do rozkładów jazdy poszczególnych przewoźników oraz brak aktualności umieszczanych informacji o odjazdach na przystankach, stronach internetowych czy w informacjach przekazywanych przedstawicielom władz samorządowych. Brak jednolitej wyszukiwarki połączeń dla całego kraju, obejmującej wszystkich (lub przynajmniej większość) przewoźników kolejowych i autobusowych prowadzących przewozy publiczne na jego terenie jest czynnikiem utrudniającym i zniechęcającym do odbycia podróży, podobnie jak sytuacje, kiedy pasażer poddany zostanie doświadczeniu polegającym na oczekiwaniu na przyjazd kursu, który widnieje w rozkładzie jazdy, lecz w rzeczywistości nie istnieje. Chaos panujący w tej dziedzinie był wielokrotnie wskazywany przez badaczy transportu jako wyraźna niedogodność (m.in. Rosik i in., 2017; Ciechański, 2019; Beim i in., 2019).

Współczesne realia organizacji transportu zbiorowego w Polsce stwarzają możliwość prowadzenia działalności na zasadach zarówno ściśle komercyjnych, jak i poprzez interwencjonistyczną politykę państwa czy samorządu lokalnego, którego organy mają możliwość zlecenia przewoźnikowi publicznemu bądź prywatnemu zadań przewozowych wraz z ich częściowym lub całkowitym dofinansowaniem. Szczególnie w drugim z obszarów rolą polityki krajowej i lokalnej powinna być odpowiedź na elementarne zapotrzebowanie mobilnościowe obywateli. Sprawowany system władzy, przy uwzględnieniu możliwości finansowych własnych oraz potencjalnych pasażerów, jak również strony 
popytowej, w odniesieniu do konieczności bądź chęci odbywania przemieszczeń, ma sposobność interwencji na rynku przewozów transportu publicznego w celu zapobieżenia negatywnym procesom, z którymi boryka się obszar wykluczony komunikacyjnie (Kwarciński, Załoga, 2019). Polityka transportowa zalicza się w ten sposób do najważniejszych wyzwań stojących przed władzami krajowymi i samorządowymi.

\section{Uwarunkowania i organizacja sieci usług na poziomie powiatowym w kontekście ośrodków miejskich}

W obowiązującym od 1999 r. podziale administracyjnym państwa polskiego poziom powiatowy został wytypowany jako ten, w ramach którego powinna zostać zapewniona obsługa mieszkańców o charakterze lokalnym - w przeciwieństwie do miast wojewódzkich, których wielkość i pełnione funkcje predysponują je do roli ośrodków o randze regionalnej. W konfrontacji z teorią ośrodków centralnych W. Christallera oraz założeniami autorów reformy administracyjnej z ostatniej dekady XX w. miastami powiatowymi winny być takie, które znajdują się przynajmniej na trzecim, patrząc od dołu, poziomie realizacji usług według ich klasyfikacji jako niższego bądź wyższego rzędu'. W latach 90. XX w. postulowano bowiem tworzenie siedzib powiatów w miastach o zaludnieniu nie mniejszym niż 10 tys. mieszkańców, natomiast jednostki te powinny osiągać stan demograficzny nie niższy niż 50 tys. osób (Wendt, 2001). Typowano więc ośrodki, które z racji swojego potencjału ludnościowego oferowały mieszkańcom podstawowy zakres usług, w tym publicznych, oraz posiadały rozwinięte zaplecze, dla którego były one lokalnymi centrami na rynku dóbr i usług oraz miejsc pracy. Znalazło to swoje odzwierciedlenie $w$ katalogu zadań własnych i zleconych powiatów, w którym wskazano m.in. na prowadzenie edukacji na poziomie ponadpodstawowym, prowadzenie szpitali ogólnych czy prowadzenie powiatowych urzędów pracy (Małecka-Łyszczek, 2013). Funkcjonowanie aparatu państwowego oraz placówek mu podległych, struktura i układ sieci osadniczej oraz dostępność czasowo-przestrzenna mają istotne znaczenie przy rozmieszczeniu usług niezbędnych do ich istnienia na poziomie lokalnym. Gwoli ścisłości należy dodać, iż wstępne założenia związane z potencjałem demograficznym powiatów i ich stolic nie zostały zachowane (Wendt,

Przy zastosowaniu takiej analogii, według obecnego podziału administracyjnego w Polsce pierwszy poziom (od dołu) z teorii ośrodków centralnych to poziom sołecki, drugi - gminny, czwarty - subregionalny, piąty - wojewódzki, szósty - metropolitalny, siódmy - stolica państwa.
2001). W 2020 r. istniało 80 powiatów o zaludnieniu nieprzekraczającym 50 tys. osób, a łączna liczba tego rodzaju wydzieleń wynosiła w tym czasie 380, czyli o ok. 100 więcej niż przewidywano przed 1999 r.

Odpowiednio skonstruowany przestrzennie i kompetencyjnie podział administracyjny państwa należy do najważniejszych działań administracji publicznej, a jego skuteczność wpływa tak na całość funkcjonowania państwa, jaki jego poszczególnych fragmentów. W polityce wewnętrznej przestrzeń powinna być podzielona w sposób, który wykorzystuje istniejące zasoby (w tym ludzkie) w sposób efektywny, przy jednoczesnej maksymalizacji skuteczności panowania nad danym terytorium. Istnienie podziałów wewnętrznych jest ściśle związane z wielkością przestrzenną państwa oraz kompetencjami jego organów władzy. Ich istota opiera się natomiast nie tylko na efektywności sprawowania polityki wewnętrznej, lecz również na przesłankach geograficznych - zarówno fizycznych (np. rzeki czy łańcuchy górskie), jak i społeczno-kulturowych (etnicznych czy językowych), a także na istniejących więziach funkcjonalno-przestrzennych (Wendt, 2001). Ten sposób decentralizacji władzy przekłada się na funkcjonowanie poszczególnych fragmentów państwa, kształtowanych przez procesy związane niejednokrotnie $z$ rangą miasta $w$ sieci osadniczej oraz z granicami istniejących wydzieleń administracyjnych.

Z perspektywy ponad dwóch dekad obowiązywania podziału administracyjnego, w ramach którego przywrócono poziom powiatowy (nieistniejący w latach 1975-1998), nie ustają kontrowersje związane z liczbą, wielkością i kompetencjami jednostek tego szczebla. Z punktu widzenia geografii transportu wszystkie wyżej wymienione aspekty są ściśle związane z tą dziedziną ludzkiej aktywności, gdyż liczba i wielkość powiatów mają wpływ na kierunki przemieszczeń, które niejednokrotnie motywowane są koniecznością bądź chęcią dostania się do usługi oferowanej jedynie w ośrodku będącym siedzibą władz powiatowych, jak również na częstotliwość ich odbywania. Kompetencje samorządu powiatowego mogą wpływać na mobilność zarówno od strony usług, jakie są z nim ściśle związane i świadczone w określonym miejscu w przestrzeni tejże jednostki, jak i od strony organizacji przewozów. Syntetyczne spojrzenie na wyżej wymienione kwestie wskazuje, iż jeśli powiatów byłoby mniej (co byłoby zgodne z pierwotnymi założeniami ostatniej reformy podziału administracyjnego (Wendt, 2001) oraz jest często poruszanym postulatem $w$ środowisku eksperckim), to ich większa powierzchnia z jednej strony przełożyłaby się na zwiększenie ich możliwości i sprawczości (oraz oszczędności finansowe aparatu biurokratycznego państwa), z drugiej zaś byłaby większym wyzwaniem 
dla organizacji lokalnego transportu. Wraz z centralizacją pewnych usług i funkcji w ramach mniejszej niż do tej pory liczby ośrodków powiatowych zaszłaby konieczność odbywania większej liczby przemieszczeń oraz, niejednokrotnie, na większe odległości. Stąd też do wszelkiego rodzaju reform bądź korekt w tym zakresie należy podchodzić ostrożnie i z uwzględnieniem różnych stanowisk środowiska naukowego i zainteresowanych obywateli - ostatnie przykłady z historii Polski służą bowiem bardziej za przestrogę niż za wzór (Wendt, 2001). Należy mieć jednak na uwadze, iż przeprowadzone kilkanaście lat po reformie z lat 1998-1999 badania wskazały, że małe jednostki samorządowe (niezależnie od poziomu podziału administracyjnego) mają większą trudność z wykonywaniem zadań własnych i zleconych w stosunku do dużych (Gendźwiłł i in., 2016).

W kontekście realizacji zadań publicznych, również transportowych, problematyczne jest administracyjne wydzielenie miast na prawach powiatu od powiatów ziemskich mających siedzibę w tymże mieście. W 2019 r. w Polsce taka sytuacja dotyczyła 39 ośrodków. Pomimo istniejących powiązań funkcjonalnych oraz większej efektywności działania aparatu państwowego i samorządowego w przypadku scalenia tych sąsiadujących ze sobą jednostek, w przypadku braku woli współpracy między lokalnymi władzami tracą mieszkańcy, w szczególności powiatu ziemskiego, pozbawieni m.in. dostępu do komunikacji miejskiej funkcjonującej w mieście powiatowym, która nie realizuje żadnych przewozów podmiejskich w wyniku braku porozumienia z samorządami sąsiednimi. Trudniej jest w ten sposób również realizować inwestycje w infrastrukturę transportową, np. w budowę bądź modernizację dróg, co mieści się w ramach kompetencji władz powiatowych. Stąd też wielu badaczy w dziedzinie organizacji usług w przestrzeni zgłasza zastrzeżenia co do funkcjonalności rozwiązania jakim jest wydzielenie części miast z powiatów ziemskich i nadanie im statusu miasta na prawach powiatu (m.in. Gendźwiłł i in., 2016).

\section{Obszar badań}

Zakres przestrzenny niniejszego opracowania ograniczony jest do obszaru Pomorza Środkowego - regionu znajdującego się w północno-zachodniej Polsce, w którego skład wchodzą fragmenty trzech województw - zachodniopomorskiego (9 powiatów), pomorskiego (5 powiatów i 1 gmina) oraz wielkopolskiego (1 powiat) (ryc. 2, ryc. 3). Granice tego terenu zostały ustalone na podstawie najbardziej obszernych terytorialnie propozycji utworzenia województwa środkowopomorskiego, przy jednoczesnym zawarciu w nim całej powierzchni województw koszalińskiego i słupskiego z okresu podziału Polski na 49 województw (lata 19751998) (Żuber, 2010). Według danych aktualnych na rok 2019, obszar ten miał powierzchnię 18986 km² i zamieszkiwany był przez 1 mln 54 tys. osób.

Pomorze Środkowe w wielu opracowaniach uznawane jest za jeden z największych fragmentów Polski, który wyróżnia się nagromadzeniem zjawisk problemowych wynikających zarówno z tamtejszego dziedzictwa, jak i współczesnego wykluczenia w podziale administracyjnym, które idzie w parze z innymi przejawami tego zjawiska, m.in. w wymiarze transportowym, gospodarczym i społecznym (m.in. Koncepcja Przestrzennego Zagospodarowania Kraju 2030, 2011; Wskaźniki dostępności terytorialnej..., 2018; Goliszek i in., 2017). Nieutworzenie w 1999 r. (bądź później) województwa środkowopomorskiego spowodowało, że region ten znalazł się na peryferiach trzech województw, między które został podzielony - to zaś przyniosło osłabienie lub zerwanie wewnętrznych powiązań w skali regionalnej i lokalnej. Niewiele mniej kontrowersji budzi obowiązujący od tego samego momentu podział tej części państwa na szczeblu powiatowym². Stąd też autor opracowania podjął się diagnozy stanu oferty przewozowej transportu publicznego na Pomorzu Środkowym, według podziału administracyjnego i rozkładów jazdy aktualnych na 2019 r. Jego celem jest wskazanie gmin najbardziej wykluczonych transportowo zarówno w odniesieniu do obowiązującego podziału administracyjnego poziomu powiatowego (a więc poziom skomunikowania miejscowości będących siedzibami urzędów gminy ze stolicami powiatów, w których się znajdują), jak również w kontekście dojazdów ludności do najważniejszych ośrodków regionu wyposażonych w dany zestaw usług w nim oferowanych, gdyż nie zawsze grupa miast będących siedzibami władz powiatowych jest tożsama z takową. W ten sposób uwzględniono zarówno więzi formalne, związane z przyporządkowaniem do aparatu państwowego, które winny odzwierciedlać rzeczywiste powiązania funkcjonalne bądź je wykreować, jak i potencjalne zachowana przestrzenne, które nie są ograniczone do granic administracyjnych i nie muszą się do nich dopasowywać.

Układ osadniczy Pomorza Środkowego jest słabo rozwinięty w porównaniu do innych części kraju - jest on bowiem rozproszony, a cały region cechuje się niską gęstością zaludnienia. Jest to efektem położenia tego obszaru w skali kraju, jego burzliwej historii oraz aspektów fizycznogeograficznych determinujących rozwój osadnictwa w okresie kształtowania się

Dotyczy to przede wszystkim nieutworzenia, a w zasadzie nieodtworzenia, istniejącego do 1975 r. powiatu miasteckiego. 


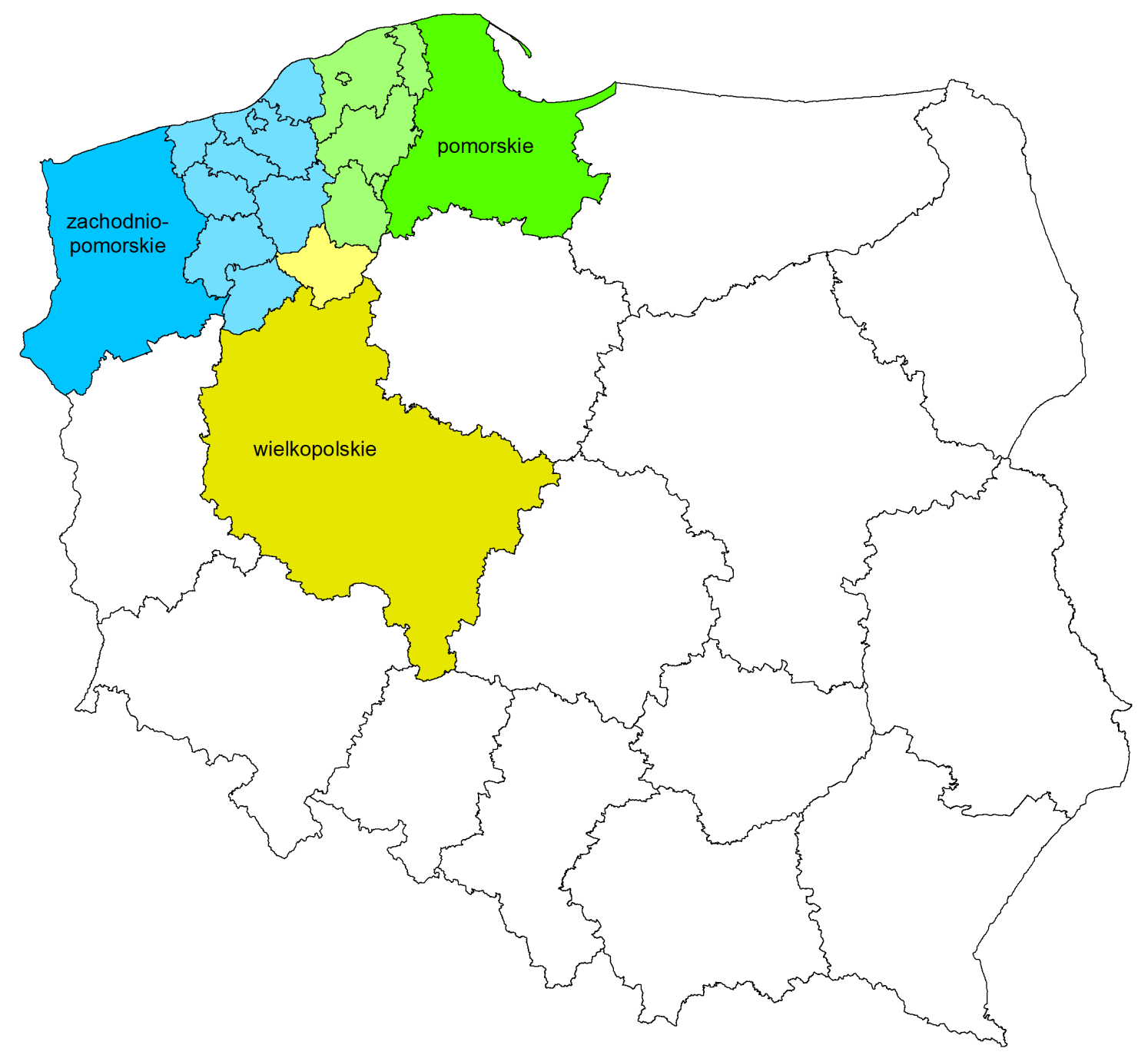

Przynależność wojewódzka:

powiaty i gminy województwa pomorskiego w granicach Pomorza Środkowego pozostały obszar województwa pomorskiego powiaty województwa wielkopolskiego w granicach Pomorza Środkowego pozostały obszar województwa wielkopolskiego powiaty województwa zachodniopomorskiego w granicach Pomorza Środkowego pozostały obszar województwa zachodniopomorskiego pozostałe województwa

$0 \quad 50 \quad 100 \quad 200 \mathrm{~km}$

Ryc. 2. Powiaty i gminy tworzące obszar badań na tle obecnego podziału administracyjnego Polski. Źródło: Opracowanie własne. 


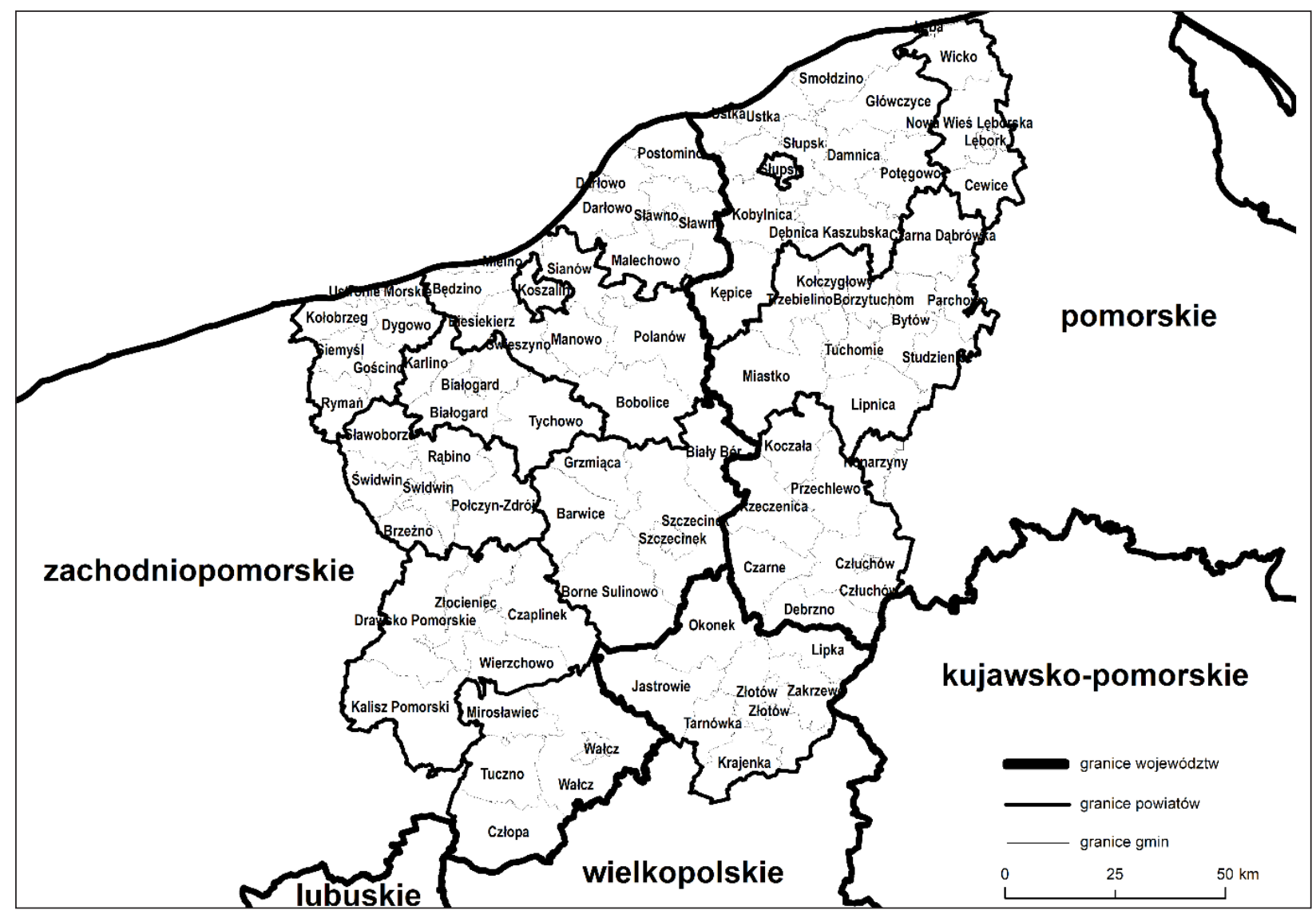

Ryc. 3. Podział Pomorza Środkowego na powiaty i gminy.

Źródło: Opracowanie własne.

miejskiej sieci osadniczej Pomorza, a więc w późnym średniowieczu (XIII-XIV w.). W ujęciu fizjograficznym, Pomorze Środkowe można podzielić na trzy pasy o równoleżnikowym przebiegu, z których największym natężeniem procesów urbanizacji odznacza się pas północny, obejmujący Pobrzeża Południowobałtyckie. Znajdują się tam główne ośrodki regionu, takie jak Koszalin, Słupsk, Kołobrzeg czy Lębork. Pozostałe pasy, a więc środkowy i południowy, położone na Pojezierzach Południowobałtyckich, cechują się przede wszystkim brakiem większych ośrodków miejskich (jedynie Szczecinek i Wałcz są zamieszkane przez więcej niż kilkanaście tysięcy osób) (Rydz, 2006). Taki układ sieci osadniczej odcisnął swoje piętno na przebiegu głównych szlaków transportowych regionu, zarówno w kontekście skomunikowania w jego obrębie, jak i z otoczeniem. Najważniejsze drogi krajowe mają tu bowiem przebieg równoleżnikowy, z których magistralną rolę pełni droga krajowa nr 6, biegnąca przez Kołobrzeg, Koszalin, Słupsk i Lębork, łącząc aglomerację szczecińską z trójmiejską. Jej zachodnia część została do 2019 r. podniesiona do standardu drogi ekspresowej (S6). Za skomunikowanie drogowe Pomorza Środkowe- go z południem Polski odpowiada droga krajowa nr 11, wraz z odgałęzieniem w postaci drogi krajowej nr 21 - łączy ona w ten sposób wszystkie największe miasta pasa nadmorskiego z Wielkopolską i południem kraju. Podobnie jak droga krajowa nr 6, jest ona sukcesywnie rozbudowywana do standardu drogi ekspresowej. Układ dróg lokalnych nie jest rozwinięty, co wynika z jego dostosowania do regionalnej sieci osadniczej, nie zaś z niedoinwestowania infrastrukturalnego tej części Polski (Bański (red.), 2016). W sieci kolejowej zauważalna jest analogia z połączeniami drogowymi - główny szlak Pomorza Środkowego stanowi linia kolejowa nr 202, o przebiegu niemal równoległym do drogi krajowej $\mathrm{nr} 6, \mathrm{z}$ uzupełnieniem w postaci linii nr 402. Linia nr 202 odznacza się najwyższym natężeniem ruchu pociągów pasażerskich w regionie. W osi północ-południe za ruch lokalny, regionalny i krajowy odpowiedzialne są linie nr 404 i 405, przebiegające odpowiednio z Kołobrzegu i Ustki, łączące się w Szczecinku i prowadzące dalej, w kierunku Piły i Poznania (na zasadzie podobnej do roli dróg krajowych nr 11 i 21 w transporcie drogowym). Poniżej wymieniono największe ośrodki miejskie Pomorza Środkowego, wraz z przypisaną im sumą rang 
(tab. 1). Metodyka została zawarta w części „Materiały źródłowe i metody analizy". ny, akty prawne) i wtórnych (m.in. literatura naukowa, wyszukiwarki rozkładów jazdy, strony internetowe

Tab. 1. Zaludnienie, pozycja w sieci osadniczej oraz przynależność powiatowa największych miast Pomorza Środkowego.

\begin{tabular}{|c|c|c|c|}
\hline Miasto $^{\mathrm{a}}$ & Liczba ludności & Suma rang & Powiat \\
\hline Koszalin & 107048 & 7 & M. Koszalin \\
\hline Słupsk & 90681 & 7 & M. Słupsk \\
\hline Kołobrzeg & 46259 & 7 & kołobrzeski \\
\hline Szczecinek & 40043 & 7 & szczecinecki \\
\hline Lębork & 35273 & 7 & lęborski \\
\hline$\underline{\text { Wałcz }}$ & 25179 & 7 & wałecki \\
\hline Białogard & 24146 & 7 & białogardzk \\
\hline Złotów & 18532 & 6 & złotowski \\
\hline Bytów & 16881 & 6 & bytowski \\
\hline Świdwin & 15468 & 3 & świdwiński \\
\hline Ustka & 15367 & 4 & słupski \\
\hline Darłowo & 13695 & 4 & sławieński \\
\hline Człuchów & 13624 & 7 & człuchowski \\
\hline Złocieniec & 12833 & 4 & drawski \\
\hline Sławno & 12528 & 6 & sławieński \\
\hline Drawsko Pomorskie & 11523 & 7 & drawski \\
\hline Miastko & 10384 & 5 & bytowski \\
\hline
\end{tabular}

a W kolumnie „Miasto" podkreślono ośrodki będące stolicami powiatów.

Źródło: Opracowanie własne.

\section{Materiały źródłowe i metody analizy}

Na podstawie wyników kwerendy danych pochodzących ze źródeł pierwotnych (m.in. dane statystyczne zbierane i publikowane przez Główny Urząd Statystycz- instytucji, prasa regionalna) opracowano poszczególne metody i techniki badawcze zastosowane do analiz przestrzennych w ujęciu skalarnym i wektorowym. Dzięki przetworzeniu ilościowemu danych staty- 
stycznych i innych informacji mających odniesienie do wymiaru przestrzennego, opracowano autorskie metody traktujące problematykę badawczą poruszaną w niniejszym opracowaniu w sposób adekwatny do realiów panujących na obszarze badań w 2019 r.

W celu określenia rangi miasta w sieci osadniczej regionu określono zbiór miejscowości Pomorza Środkowego posiadających prawa miejskie w 2019 r., a następnie na podstawie dostępnych źródeł opracowano informacje aktualne na ten rok o lokalizacji w tych ośrodkach wybranych pięciu rodzajów placówek usługowych: szkół ponadpodstawowych, szpitali, sądów rejonowych, urzędów skarbowych oraz kin. Ich rola w obsłudze lokalnej społeczności jest powszechna, a dobór ten został dokonany wedle założenia ich różnorodności - reprezentują one bowiem usługi edukacyjne, medyczne, sądownicze, administracyjne i kulturowe (por. Sołtys, 2013; Wendt, 2001). Dane te wykorzystano w skonstruowanym na potrzeby opracowania wskaźniku, pozwalającym na ustalenie rangi miasta oraz konfrontacji tegoż zagadnienia z obecnie istniejącym podziałem terytorialnym na szczeblu powiatowym. Jeśli w danym ośrodku znajdowała się dana placówka, to przyporządkowywano mu wartość 1, jej brak oznaczał zaś przypisanie mu wartości 0. Dodatkowo, jeden punkt otrzymały miejscowości, które osiągnęły zaludnienie na poziomie przynajmniej 10 tys. osób, a kolejny punkt za możliwość dotarcia do nich regularnymi połączeniami pasażerskimi transportu kolejowego. W efekcie maksymalna suma wartości, jaką miasto mogło osiągnąć wyniosła 7, minimalna 0 (metoda skalarna). Zrezygnowano z włączenia do analizy ośrodków nieposiadających praw miejskich, lecz spełniających przynajmniej jeden z siedmiu postawionych warunków, gdyż nadrzędnym celem opracowania jest określenie rangi w układzie osadniczym wyłącznie miast. Na podstawie tej metody sporządzono hierarchię ośrodków w następujących ujęciach:

- miasta osiągające sumę wartości wynoszącą przynajmniej 5 jako ośrodki, które są na tyle rozwinięte, iż pełnienie przez nie funkcji miasta powiatowego nie powinno budzić wątpliwości;

- miasta osiągające sumę wartości wynoszącą przynajmniej 4 jako ośrodki potencjalnie przygotowane do bycia stolicą powiatu, choć taka rola wymagałaby ich wzmocnienia w sferze instytucjonalnej i usługowej.

Jak wyżej wspomniano, dobór cech danych ośrodków był podyktowany specyfiką regionu oraz założeniem dotyczącym dużego zróżnicowania branych pod uwagę informacji - zarówno lokalizacji placówek usługowych, jak i wielkością oraz dostępnością komunikacyjną. Założenie o wielkości miasta powiatowego według jego liczby ludności wynoszącej przynajmniej 10 tys. mieszkańców pochodzi wprost z lat 90. i eksper- ckich opracowań w tym zakresie, które miały zostać wcielone w życie w ramach reformy z lat 1998-1999. Dostępność kolejowa miast powiatowych jest aspektem w znaczny sposób ułatwiającym mieszkańcom przemieszczenia, gdyż oferta na liniach kolejowych jest często bardziej rozbudowana i ma charakter bardziej stały niż komunikacja autobusowa. Pozostałe części wskaźnika, odnoszące się do oferowanych w nich usług, są oparte zarówno na literaturze przedmiotu, zadaniach stojących przed władzami powiatowymi, jak również na cechach wyróżniających miasta powiatowe oraz potencjalnie mogące pełnić takie funkcje. Inspiracją do wdrożenia takiej procedury badawczej była teoria ośrodków centralnych W. Christallera, która zakłada, iż odpowiedniej wielkości ośrodki pełnią (lub powinny pełnić) określone funkcje nadrzędne wobec mniejszych miejscowości, co powinno znaleźć swoje odzwierciedlenie również w podziale administracyjnym.

Wyniki metody rangowania odniesiono również do danych dotyczących dostępności transportowej tychże ośrodków, którą to określono za pomocą innego autorskiego wskaźnika, opierającego się na analizie połączeń transportem zbiorowym do miast z poziomu miejscowości gminnych Pomorza Środkowego (metoda wektorowa). Miejscowości te zostały potraktowane jako istotne punkty wejścia do systemu transportowego, pozwalającego na dotarcie do miast w których oferowane są niezbędne dla mieszkańców usługi, a więc takich, w których mieści się przynajmniej jedna z pięciu placówek wymienionych w poprzednich akapitach. W sytuacji, gdy dane połączenie pozwalało na dotarcie do więcej niż jednego z nich, wybierano wyłącznie pierwsze na podstawie najkrótszego czasu przejazdu, odrzucając te, do których można przemieścić się wyłącznie przez inne, również uwzględnione w badaniu. Na potrzeby metody scalono gminy, których siedziby znajdowały się w miejscowości położonej poza jej granicami, z tymi, gdzie zlokalizowano odpowiedni dla nich urząd gminy. Takie postępowanie pozwoliło na zachowanie porównywalności analiz, gdyż nie wszystkie miasta w układzie gminnym są jednostkami wydzielonymi od ich wiejskiego zaplecza, funkcjonując jako gminy miejsko-wiejskie. Wyjątkowo została potraktowana gmina wiejska Słupsk, której siedziba znajduje się w mieście Słupsk, gdyż scalenie tych dwóch gmin oznaczałoby przecięcie granicy powiatu (Słupsk jest miastem na prawach powiatu), co spowodowałoby komplikacje metodyczne.

Siła powiązań funkcjonalnych oraz poziom atrakcyjności istniejącej oferty transportu zbiorowego między daną gminą a ośrodkiem posiadającym prawa miejskie zostały określone według następującego wzoru: średni czas przejazdu transportem zbiorowym w dniu roboczym (przy uwzględnieniu wszyst- 
kich bezpośrednich połączeń w ciągu jednej doby) z miejscowości gminnej do danego ośrodka, liczony w minutach, dzielony przez liczbę bezpośrednich połączeń na dobę (również w dniu roboczym). Interpretacja takiego wskaźnika jest następująca - im niższy wynik otrzymano, tym notowano większe powiązania funkcjonalne między ośrodkami oraz tym lepsza była jakość oferty transportowej między nimi. Wzór ten pozwala na uwzględnienie najbardziej istotnych z punktu widzenia pasażera zmiennych ilościowych, czyli liczby bezpośrednich połączeń oraz czasu przejazdu (por. Guzik (red.), 2012). Nie uwzględniono aspektów jakościowych czy też odczuć subiektywnych, odrzucono również model podróży z przesiadką, chyba że z danej miejscowości gminnej nie było możliwe dostanie się do odpowiedniego miasta w inny sposób. W takiej sytuacji, oprócz sumy czasów przejazdu, założono dodatkowe 10 minut na przesiadkę w najlepiej skomunikowanej miejscowości w kontekście dalszej podróży, natomiast w części dotyczącej liczby połączeń wybrano najmniejszą z osobnych etapów przejazdu, gdyż (przykładowo) jeśli w drugim z nich dostępnych jest osiem połączeń na dobę, to pasażer ma możliwość skorzystania wyłącznie z sześciu z nich, jeśli taka ich liczba jest oferowana w pierwszym etapie. Czas przejazdu między miejscowościami oparto na danych pochodzących z przystanków, stacji lub dworców głównych dla nich - w większych miastach wybór ten był jednoznaczny, w mniejszych miejscowościach sugerowano się położeniem przystanków przy urzędach gminy lub najważniejszym skrzyżowaniu. Uwzględniono również połączenia, których trasy przebiegały przez dane miejscowości peryferyjnie, wybierając wówczas zatrzymania położone najbliżej określonych miejsc głównych. W sytuacji, w której z danej miejscowości gminnej dostępność transportowa do dwóch miast była taka sama (przy zaokrągleniu do części dziesiętnej wyniku), kierowano się jej przynależnością powiatową, wybierając ośrodek znajdujący się w tym samym wydzieleniu co gmina. Ze względu na wyraźnie większą siłę oddziaływania Koszalina i Słupska jako zdecydowanie największych miast regionu (są to ośrodki regionalne, wszystkie pozostałe są co najwyżej w randzie subregionalnej (Koncepcja Przestrzennego Zagospodarowania Kraju 2030, 2011)), zdecydowano się na wprowadzenie „para-grawitacyjnego" czynnika, tzn. jeśli z danej miejscowości gminnej oferta komunikacyjna do danego ośrodka była dwukrotnie mniejsza do Koszalina lub Słupska, to przypisywano jej ciążenia właśnie do mniejszego z miast. Sytuacja taka miała miejsce m.in. w gminach Postomino czy Trzebielino. Inne, bardziej skomplikowane metodycznie sytuacje nie wystąpiły w badaniu. Wszystkie procedury badawcze - dotyczące zarówno cech miast, jak i istniejących połączeń transportowych - zostały oparte na danych aktualnych na 2019 r.

Otrzymane wyniki zostały zinterpretowane w sposób następujący:

1. Od 0,1 do 1,0 - skomunikowanie wzorcowe;

2. Od 1,1 do 2,5 - skomunikowanie optymalne, zasadniczo niewymagające poprawy;

3. Od 2,1 do 5,0 - skomunikowanie zapewniające możliwość odbycia podróży w celu nabycia dobra lub usługi, lecz wymagające korekt;

4. Od 5,1 do 10,0 - skomunikowanie niewystarczające, powodujące uciążliwości w dojazdach codziennych; Powyżej 10,0 - skomunikowanie całkowicie niezadowalające, czyniące codzienne dojazdy niemożliwymi lub prawie niemożliwymi.

Autor ma świadomość, iż zastosowana metodyka jest pewnym uproszczeniem rzeczywistości, w której na faktyczne ciążenia składają się nie tylko aspekty związane z czasem przejazdu między miejscowościami czy liczbą dostępnych połączeń. Istotną rolę dla potencjalnego pasażera mogą mieć również takie czynniki jak komfort podróży, wysokość opłat za przejazd, dostępność przestrzenna miejsca zatrzymania pojazdu, doświadczenia związane z poprzednimi podróżami itp. Niemniej jednak na potrzeby niniejszego badania nie było możliwe przeprowadzenie tak szeroko zakrojonych badań, które umożliwiłyby zebranie odpowiednich danych w tym zakresie, a w konsekwencji na użycie rozbudowanych metod badań dostępności, np. często stosowanej w podobnych opracowaniach dostępności potencjałowej (Rosik i in., 2018). Dokładniejsze wyniki w kontekście ciążeń mogłyby zostać uzyskane dzięki metodom grawitacyjnym (por. Guzik i in., 2020); stosunkowo wiarygodne informacje można otrzymać również dzięki uwzględnieniu dodatkowych zmiennych, takich jak wielkości strumieni dojazdów do pracy. Wielkość rzeczywistych powiązań funkcjonalnych uwiarygodniłyby również badania systematyczne, co poprzez porównywalność zebranych i opracowanych danych, wskazywałoby na zmiany w tym zakresie lub ich brak. Potwierdzałoby to m.in. słuszność istniejących wydzieleń, poprzez zauważanie zmiany polityki lokalnej, przekładającej się na zwiększenie ciążeń między daną gminą a ośrodkiem powiatowym, pod który podlega, bądź też przeciwnie - wskazywałoby na ewidentną dysfunkcjonalność istniejących granic, gdyby sytuacja gmin ciążących do innych ośrodków władzy powiatowej nie poprawiałaby się lub nawet pogarszała w odniesieniu do ich miasta powiatowego. Takie badania, w szczególności kompleksowe, są jednak prawie niemożliwe do przeprowadzenia, ze względu niedostępność danych archiwalnych dotyczących rozkładów jazdy. 


\section{Wyniki}

W kontekście skomunikowania miejscowości gminnych z odpowiednimi dla nich miastami powiatowymi, według obowiązujących w 2019 r. wydzieleń administracyjnych, zauważyć można, że w zdecydowanie korzystniejszej komunikacyjnie sytuacji byli mieszkańcy powiatów położonych w północnej części Pomorza Środkowego (ryc. 4.). We wszystkich powiatach nadmorskich oraz w sąsiadujących z nimi powiatach białogardzkim i świdwińskim większość gmin znajdująca się w ich granicach była skomunikowana z ośrodkiem władzy tego szczebla podziału administracyjnego w sposób wzorcowy bądź optymalny, a więc osiągnęła wynik nie większy niż 2,5 . Nieliczne odstępstwa od tej reguły dotyczyły głównie gmin położonych peryferyjnie w dużych powiatach, takich jak koszaliński czy słupski. Zdecydowanie odmienna sytuacja charakteryzowała pozostałą część regionu. We wszystkich pozostałych powiatach liczba gmin z wynikiem nieprzekraczającym 2,5 nie była większa niż 2 (oprócz złotowskiego). Sytuacja taka wynikała z niskiej gęstości zaludnienia i słabo rozwiniętej sieci osadniczej, co zdeterminowało niewielki potencjał ludnościowy tych obszarów pomimo ich rozległości powierzchniowej, a także oddalenie od głównych szlaków komunikacyjnych Pomorza Środkowego. W konsekwencji, wskazać można obszary wyraźnie problemowe pod kątem możliwości odbycia przemieszczenia do miasta powiatowego z miejscowości gminnej - powiat wałecki, gdzie dwie z trzech gmin osiągnęły wynik wyższy niż 2,5 , powiat drawski, gdzie dwie z czterech gmin były skomunikowane z Drawskiem Pomorskim niewystarczająco (rezultaty w przedziale 5,1 - 10,0) (z jednej z nich, mianowicie z gminy Wierzchowo, do ośrodka władzy powiatowej można było dostać się wyłącznie z przesiadką w Złocieńcu), jak również powiat bytowski, gdzie pięć z dziewięciu gmin osiągnęło wyniki wyższe niż $5,0, z$ których dwie przekroczyły wartość 10,0. Szczególną uwagę należy zwrócić na obszar położony między Słupskiem, Bytowem i Szczecinkiem, a więc istniejącego do 1975 r., lecz nieodtworzonego, powiatu miasteckiego, który tworzyły do 1975 r. gminy Miastko, Kępice, Trzebielino, Biały Bór i Koczała. Ta część Pomorza Środkowego, podzielona między cztery powiaty, głównie z racji braku przywrócenia funkcji powiatowych Miastku, jest w większości połączona transportowo z "nowymi" miastami powiatowymi w sposób całkowicie niezadowalający. Dotyczy to gmin Miastko i Trzebielino w powiecie bytowskim oraz gminy Koczała w powiecie człuchowskim (dodatkową uciążliwością dla mieszkańców Trzebielina była konieczność odbycia podróży z przesiadką w Miastku z racji braku połączeń bezpośrednich do Bytowa). Położona nieopodal gmi- na Polanów borykała się z podobnymi problemami, gdyż była ona lepiej skomunikowana z Miastkiem niż Koszalinem, mimo iż znajduje się w powiecie koszalińskim. Całkowicie zatarły się w tym mieście więzi ze Sławnem, chociaż do 1975 r. ośrodek ten znajdował się w powiecie sławieńskim (brak połączeń bezpośrednich do Sławna). Pozostałe gminy cechujące się całkowicie niezadowalającym poziomem skomunikowania z ośrodkiem powiatowym, przynależą do tej grupy w wyniku przede wszystkim bardzo słabo rozwiniętej oferty połączeń, wynoszącej w skrajnych przypadkach zaledwie dwa w ciągu doby (gminy Tarnówka i Konarzyny).

W wariancie alternatywnym, zgodnie z procedurą opisaną w części „Materiały źródłowe i metody analizy", wskazano miasta, które w metodzie rangowania osiągnęły sumę wartości wynoszącą przynajmniej 5 , a więc były one wystarczająco rozwinięte, aby pełnić funkcje powiatowe (niezależnie od tego, czy w rzeczywistości je pełniły, czy też nie). Następnie, na podstawie określonych kierunków powiązań funkcjonalnych, przypisano im poszczególne gminy według największych ciążeń komunikacyjnych, tworząc $w$ ten sposób alternatywne w stosunku do stanu rzeczywistego ośrodki władzy powiatowej oraz obszary im podległe (ryc. 5). W takim scenariuszu likwidacji uległby powiat świdwiński, utworzony zostałby natomiast powiat miastecki, w miejsce zniesionego w 1975 r. wydzielenia, które nie zostało później przywrócone. Pozostałe korekty dotyczyłyby zmiany przynależności powiatowej kilku gmin, gdyż dzięki zastosowanej metodzie badawczej wskazano przykłady, w których z miejscowości gminnej łatwiej można było dostać się transportem zbiorowym do ośrodka powiatowego znajdującego się w innym powiecie niż dana gmina. Stąd też zaproponowany przez autora alternatywny podział Pomorza Środkowego na powiaty $z$ definicji winien odzwierciedlać rzeczy wiste więzi, które niejednokrotnie przecinają granice istniejących wydzieleń, jak również opierać się na możliwości zaspokojenia potrzeb ludności $w$ dobra i usługi na poziomie lokalnym według funkcji usługowych, które miasto pełni, a nie wyłącznie na jego statusie w podziale administracyjnym kraju. Powstały w ten sposób powiat miastecki zdecydowanie wpłynąłby na zniwelowanie stosunkowo rozległego, bo składającego się z kilku gmin, obszaru, który skomunikowany był z miastem powiatowym w sposób niezadowalający. Ciążenia tych gmin skierowane były do Miastka, które było wystarczająco rozwiniętym ośrodkiem, aby zapewnić obsługę swojego zaplecza. Zauważalną korzyść odnieśliby również mieszkańcy gmin Postomino i Okonek, które zostałyby przeniesione odpowiednio z powiatu sławieńskiego do słupskiego oraz ze złotowskiego do szczecineckiego. Pewnym utrudnieniem dla potencjal- 


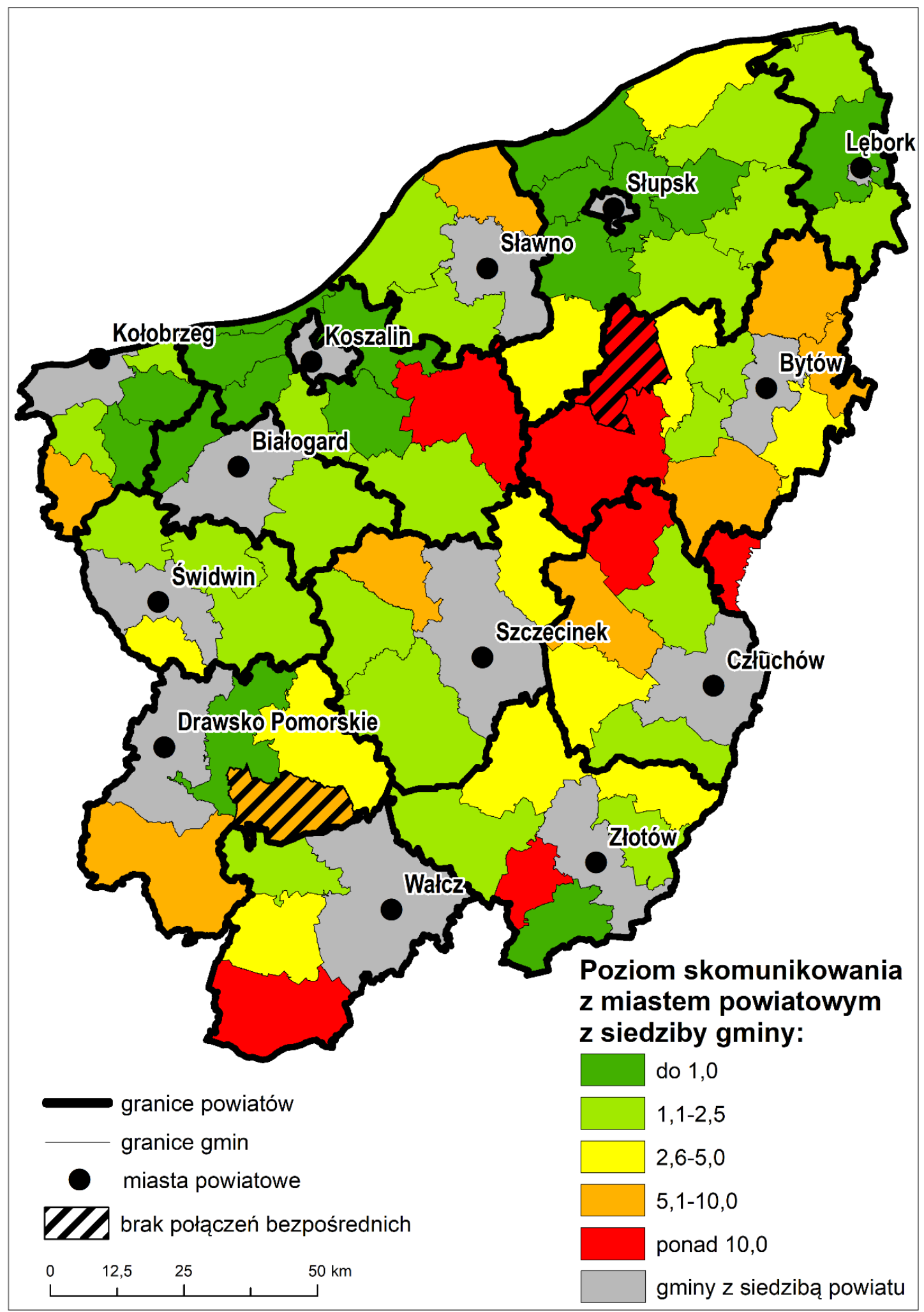

Ryc. 4. Poziom skomunikowania z poziomu miejscowości będących siedzibami władz gminnych z miastem powiatowym na Pomorzu Środkowym.

Źródło: Opracowanie własne. 


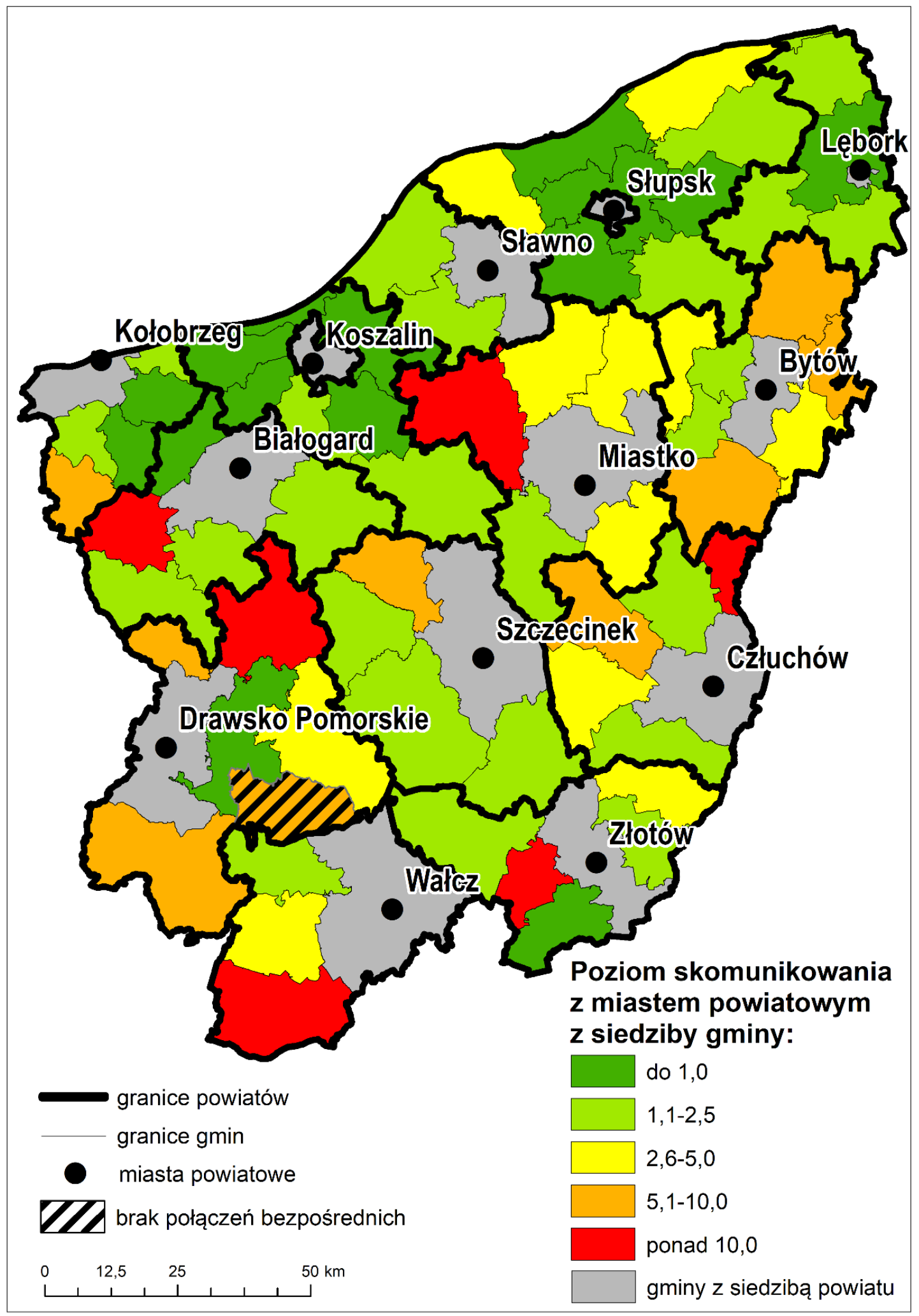

Ryc. 5. Poziom skomunikowania z poziomu miejscowości będących siedzibami władz gminnych z miastem powiatowym według wariantu alternatywnego na Pomorzu Środkowym.

Źródło: Opracowanie własne. 
nych pasażerów byłaby natomiast likwidacja powiatu świdwińskiego, szczególnie dla mieszkańców gmin Połczyn-Zdrój i Sławoborze, które odznaczałyby się skomunikowaniem na poziomie niezadowalającym z nowymi ośrodkami władzy powiatowej, jakimi byłyby dla nich odpowiednio Drawsko Pomorskie i Białogard, względem optymalnej oferty połączeń do Świdwina. Należy jednak zauważyć, że po pierwsze, bogata oferta połączeń autobusowych z tych miejscowości do Świdwina tworzyła wyłącznie iluzoryczną dostępność, gdyż w Świdwinie nie oferowano niemal żadnych usług rangi powiatowej, a mieszkańcy i tak zmuszeni byli do odbywania podróży w innych kierunkach. Po drugie zaś, w przypadku ewentualnych korekt podziału administracyjnego, władze powiatów białogardzkiego i drawskiego, w których gminy te znalazłyby się, zapewne dążyłyby do poprawy tak niekorzystnego dla osób zamieszkujących podległe im terytorium stanu, co rozwiązałoby ten problem.

Podjęto się również wskazania gmin, które borykały się ze zjawiskiem wykluczenia komunikacyjnego. W zbiorze tym znalazły się te jednostki, których poziom skomunikowania z najbliższym miastem, które osiągnęło sumę rang wynoszącą przynajmniej 4 , był wyższy niż 5,0, a więc niewystarczający bądź całkowicie niezadowalający (ryc. 6). Otrzymane rezultaty wskazały na najtrudniejszą sytuację mieszkańców trzech z pięciu gmin powiatu świdwińskiego, które znalazły się w tym zestawieniu. Stanowiło to konsekwencję tego, iż najbliższe rozwinięte pod kątem wyposażenia w usługi ośrodki znajdowały się poza granicami tego powiatu. Były to Drawsko Pomorskie (dla gmin Brzeżno i Połczyn-Zdrój) oraz Białogard (dla pozostałych gmin). Powiat świdwiński był jedyną jednostką, w obrębie której nie znajdowało się choć jedno miasto osiągające wynik wynoszący przynajmniej 4. Również w powiecie bytowskim wyróżniono trzy gminy, z których stolic oferta połączeń transportu zbiorowego była niewystarczająca - Czarna Dąbrówka, Parchowo i Lipnica. Mimo iż wszystkie z nich leżały przy drogach wojewódzkich, łączących Bytów z sąsiednimi ośrodkami powiatowymi (odpowiednio z Lęborkiem, Kartuzami i Chojnicami), liczba połączeń autobusowych pokonujących te trasy była zdecydowanie zbyt niska, aby zaspokoić podstawowe potrzeby związane z przemieszczeniami (między 4 a 7 kursów w ciągu doby). Jeszcze bardziej jaskrawe przykłady niedostatecznego skomunikowania stanowiły Rzeczenica i Człopa, położone odpowiednio przy drogach krajowych $\mathrm{nr} 25$ i 22, którymi to ciągami komunikacyjnymi dostać się można było z tych miejscowości do Człuchowa oraz do Wałcza. Oferta przewozowa wynosiła tu zaledwie pięć (Człopa) lub sześć (Rzeczenica) połączeń. W zestawieniu znalazła się również jedna gmina leżąca wzdłuż linii kolejowej, która łączy ją z najbliższym wyposażonym w większość branych pod uwagę usług ośrodkiem, mianowicie gmina Grzmiąca, znajdująca się w pobliżu Szczecinka. Zazwyczaj możliwość odbycia podróży pociągiem przy regularnych kursach pasażerskich wpływa pozytywnie na skomunikowanie między ośrodkami, jednak liczba regionalnych połączeń kolejowych na tej trasie była zbyt niska (zaledwie pięć), a uzupełnienie w postaci komunikacji autobusowej nie rozwiązywało niedostatków w ofercie (wyłącznie dwa kursy, o znacznie dłuższym czasie przejazdu niż pociągiem). Pozostałe gminy uwzględnione w zestawieniu, takie jak Polanów, Konarzyny czy Tarnówka, stanowiły jedne z najsłabiej skomunikowanych jednostek z otoczeniem, nawet gdyby odrzucony został warunek ustalający kierunek podróży do miasta z sumą rang wynoszącą przynajmniej cztery. Z położonego na wysoczyźnie morenowej, bardzo małego miasta powiatu koszalińskiego, oddalonego od głównych szlaków komunikacyjnych, odjazdy były możliwe wyłącznie w kierunku powiatowego Koszalina (cztery kursy) bądź bliższego Miastka (trzy kursy). Konarzyny, znajdujące się w powiecie chojnickim, nawet z ośrodkiem powiatowym, nie branym pod uwagę w zestawieniu, połączone były bardzo słabo - dwa odjazdy w ciągu doby; oferta w kierunku Człuchowa była nieznacznie gorsza. Z Tarnówki kursowały wyłącznie dwa autobusy dziennie do pobliskiego Złotowa, które tworzyły całą ofertę przewozową dostępną dla mieszkańców tej miejscowości. Trudną sytuację komunikacyjną mieszkańców okolic Złotowa opisano m.in. w lokalnych mediach (Guhs, 2018).

\section{Dyskusja}

Jak wcześniej wspomniano, obszar Pomorza Środkowego bądź jego poszczególne fragmenty, wymieniane są zarówno w opracowaniach politycznych, jak i naukowych jako tereny wykluczone pod kątem dostępności transportowej do ośrodków władzy lub poszczególnych usług. Na podstawie rezultatów przeprowadzonego postępowania badawczego wskazano zwarty obszar kilku gmin położonych w centralnej części obszaru badań, na który składały się gmina Miastko wraz z sąsiednimi wydzieleniami tego poziomu. Przestrzeń ta została wskazana, choć w nieco innym ujęciu, w opracowaniu Dostępność przestrzenna do usług publicznych w Polsce z 2017 r., autorstwa zespołu naukowców Polskiej Akademii Nauk (PAN). Można w nim bowiem przeczytać, że „obszary o najsłabszej dostępności, o czasie dojazdu do starostwa powiatowego przekraczającym $40 \mathrm{~min}$, tworzą bardziej zwarte obszary, największe (...) na pograniczu województw pomorskiego i zachodniopomorskiego", co jest tożsame $z$ terenem dawnego powiatu miasteckiego. Rozmieszczenie innych placówek usługo- 


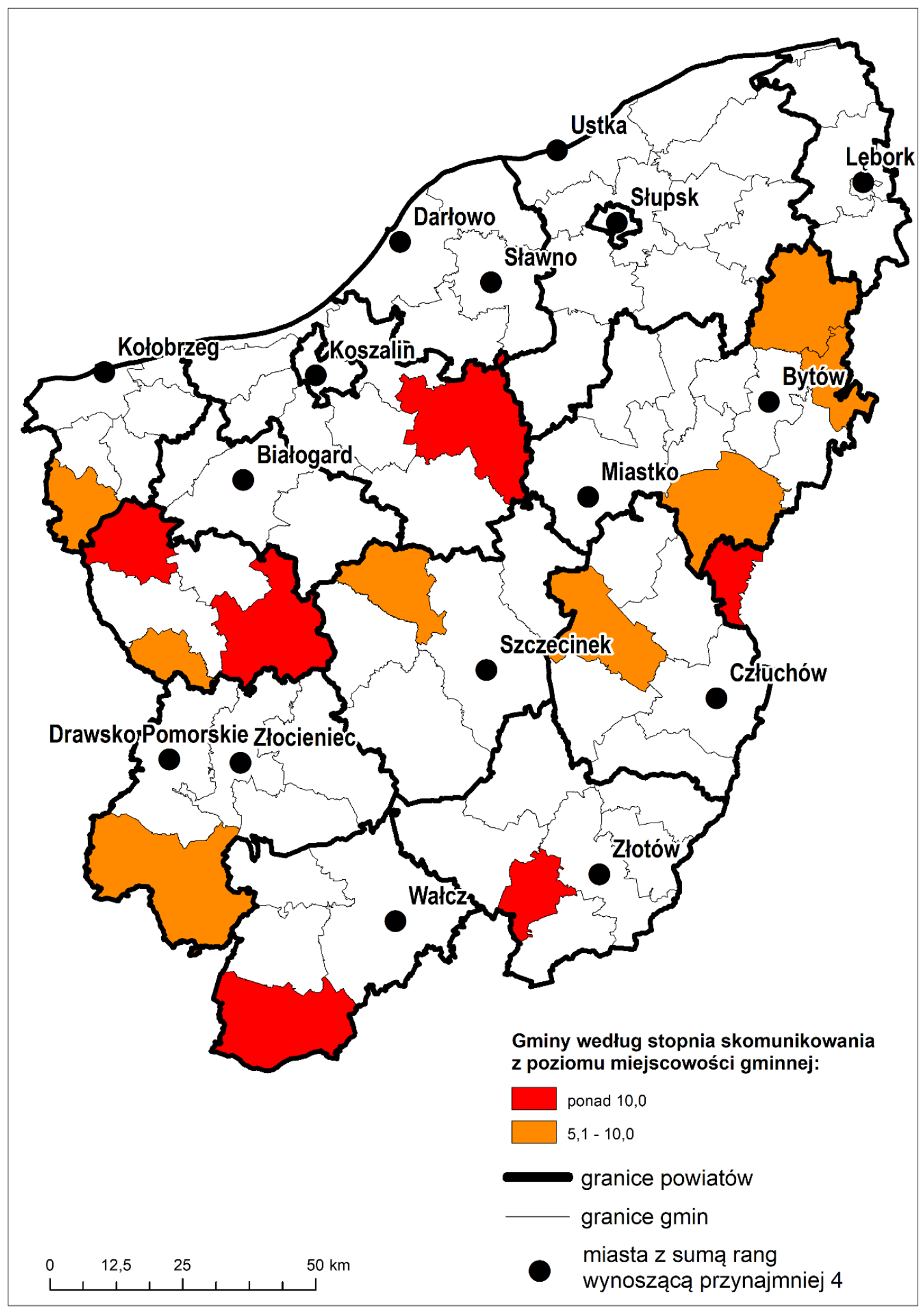

Ryc. 6. Poziom skomunikowania z poziomu miejscowości będących siedzibami władz gminnych z miastem, które osiągnęło sumę rang wynoszącą przynajmniej 4 na Pomorzu Środkowym z uwzględnieniem wyłącznie poziomu skomunikowania o wartości wyższej niż 5,0.

Źródło: Opracowanie własne. 
wych, które zostały uwzględnione w badaniu, miało również znaczący wpływ na konieczność odbywania przemieszczeń przez lokalną ludność, co stwarzało potencjalną możliwość do korzystania z transportu publicznego, jednak nie w każdym przypadku stopień skomunikowania z ośrodkiem oferującym daną usługę był wystarczający. Do podobnych wniosków doszli autorzy cytowanego wyżej opracowania, wskazując, iż „rozkład przestrzenny pozostałych placówek szkolnych (szkolnictwo ponadgimnazjalne) nawiązuje do układu sieci miejskiej w Polsce", co wyraźnie wskazuje na wykluczenie wschodniej części Pomorza Środkowego. Natomiast w kontekście dostępności przestrzennej wskazali oni południową i wschodnią część województwa zachodniopomorskiego jako obszary o niskim poziomie dostępności, co w szczególności tyczyć się może powiatów wałeckiego i szczecineckiego. Jako obszary o najmniejszej liczbie szkół ponadgimnazjalnych położonych w odległości do 30 min jazdy od miejsca zamieszkania wymienili m.in. środkowo-zachodnią część województwa pomorskiego (okolice Miastka) oraz środkowo-południową część województwa zachodniopomorskiego (powiat wałecki). Z drugiej strony pozytywnie wyróżniony został układ bipolarny dwóch ośrodków regionalnych, mianowicie Koszalina i Słupska, który poprawia dostęp przestrzenny do szkolnictwa uczniom z okolicy. Podobnego rodzaju stwierdzenia można znaleźć również $w$ treści kartograficznej raportu GUS (2018) Wskaźniki dostępności terytorialnej mieszkańców Polski do wybranych obiektów użyteczności publicznej (zarówno w kontekście usług edukacyjnych, jak i innych, np. sądowniczych) czy też w opracowaniu R. Guzika (2003) Przestrzenna dostępność szkolnictwa ponadpodstawowego. W monografii autorstwa P. Rosika i in. (2017) podobnie jak szkolnictwo ponadpodstawowe traktuje się dostępność do szpitalnych oddziałów ratunkowych, wskazując na wiele gmin województw zachodniopomorskiego i pomorskiego jako przykłady jednostek o najniższym poziomie dostępności w skali kraju, oraz do urzędów skarbowych („najgorsza dostępność charakteryzuje (...) zachodnią część województwa pomorskiego i wschodnią część zachodniopomorskiego" - wynika to głównie z braku tego rodzaju placówek w Sławnie i Miastku, na pograniczu tychże województw). W kontekście wyłącznie dostępności transportu autobusowego P. Rosik i in. (2018) wymieniają Pomorze Środkowe jako jeden z obszarów o najgorszej dostępności w podróżach krótkich, a więc adekwatnych dla badanego poziomu lokalnego. Podobny wniosek można wysnuć z badań M. Beima i in. (2019), które dotyczą co prawda wyłącznie subregionu pilskiego, jednak obejmują w ten sposób powiat złotowski, który należał do jednych ze słabiej skomunikowanych wewnętrznie fragmentów Pomorza Środkowego.

\section{Podsumowanie}

Na podstawie przeprowadzanych badań wskazano gminy Pomorza Środkowego, które borykają się ze zjawiskiem wykluczenia transportowego, a ich mieszkańcy mogą mieć wyraźną trudność $w$ dotarciu do ośrodka, w którym odpowiednie dla poziomu lokalnego dobra i usługi są oferowane. W opracowaniu poruszono ten wątek zarówno w kontekście dostępności ośrodków władzy powiatowej, jak i niezależnych od podziału administracyjnego placówek. W kontekście pierwszej z obu grup, z wyraźnym wykluczeniem komunikacyjnym borykały się położone peryferyjnie gminy powiatu bytowskiego oraz okolice Miastka, a więc obszar na pograniczu województw zachodniopomorskiego i pomorskiego, posiadając pewien obszar wspólny (zachodnia część wspomnianego powiatu). Druga z sytuacji dotyczyła głównie kilku gmin powiatu bytowskiego, jak również znacznej części powiatu świdwińskiego. W obu przypadkach był to efekt niedostatków w ofercie transportowej, a dodatkowo w okolicach Bytowa znacznej rozległości przestrzennej powiatu przy braku konkurencyjnych ośrodków w sąsiedztwie. Natomiast w powiecie świdwińskim wiązało się to z niską pozycją miast znajdujących się w obrębie tego wydzielenia w hierarchii wyposażenia w usługi, co powodowało konieczność udania się poza jego granice $w$ celu ich nabycia. Niezależnie od przyjętych założeń, z wykluczeniem komunikacyjnym borykały się gminy położone peryferyjnie w sieci osadniczej i układzie komunikacyjnym regionu, skąd liczba kursów transportu zbiorowego do sąsiednich ośrodków miejskich nie przekraczała kilku (m.in. gminy Konarzyny, Tarnówka czy Polanów). Wykazano również, iż więzi funkcjonalne, określone na podstawie ciążeń komunikacyjnych, nie zawsze odzwierciedlają ramy podziału administracyjnego, w którym są zamknięte. W korespondencji z literaturą naukową, opublikowaną kilka lub kilkanaście lat wcześniej, zauważalna jest trwałość zjawiska wykluczenia transportowego i niskiej dostępności do wielu usług w obrębie całego Pomorza Środkowego lub poszczególnych części regionu. Może to doprowadzać do pogłębiania się negatywnych zjawisk, gdyż pochodną wykluczenia transportowego i administracyjnego są problemy związane z pauperyzacją społeczeństwa oraz osłabieniem możliwości rozwojowych tamtejszej ludności w wymiarze społecznym i ekonomicznym. Wskazane wnioski posłużyć mogą jako rekomendacje dla decydentów związanych z polityką transportową w regionie, jak również przyczynić się do zmian w podziale administracyjnym lub rozmieszczeniu wybranych usług. 


\section{Piśmiennictwo}

Bański J. (red.), 2016, Atlas obszarów wiejskich w Polsce, IGiPZ PAN, Warszawa.

Beim M., Błażeczek A., Dąbrowska A., Dębiak P., Olczyk A., 2019, Badania dostępności publicznego transportu zbiorowego w podregionie pilskim, Prace Komisji Geografii Komunikacji Polskiego Towarzystwa Geograficznego, 22(4), 95-118.

Ciechański A., 2019, Wyzwania w badaniach sieci pozamiejskiego transportu autobusowego na przykładzie powiatów Beskidu Niskiego i Bieszczadów, Prace Komisji Geografii Komunikacji PTG, 22(2), 74-81.

Ciechański A., 2020, Bariery w przemieszczaniu się osób dorosłych na obszarach wykluczonych transportowo - przykład rejonu Komańczy, Prace Komisji Geografii Komunikacji PTG, 23(5), 34-52.

Gendźwiłł A., Kurniewicz A., Łukomska J., Swianiewicz P., 2016, Wielkość gmin i powiatów a sprawność ich funkcjonowania. Hipotezy wielkoludówi liliputów, Wydawnictwo Scholar, Warszawa.

Goliszek S., Marcińczak S., Stępniak M., Wiśniewski R., 2017, Dostępność przestrzenna do usług publicznych w Polsce, Prace Geograficzne nr 261, IGiPZ PAN, Warszawa.

Guhs T., 2018, Bilet do Złotowa poproszę? Czym i za ile dojedziemy do miasta, https://zlotowskie.pl/artykul/bilet-do-zlotowa-poprosze/476496 [dostęp: 18.08.2021].

Guzik R., 2003, Przestrzenna dostępność szkolnictwa ponadpodstawowego, Instytut Geografii i Gospodarki Przestrzennej Uniwersytetu Jagiellońskiego, Kraków.

Guzik R. (red.), 2012, Czynniki i ograniczenia rozwoju miast województwa pomorskiego wświetle relacji przestrzennych idostępności komunikacyjnej, Opracowanie na zlecenie Urzędu Marszałkowskiego Województwa Pomorskiego, Gdańsk.

Guzik R., Kołoś A., Fiedeń Ł., Kocaj A., Wiedermann K., 2020, Dostępność komunikacyjna i relacje przestrzenne w województwie pomorskim, Instytut Geografii i Gospodarki Przestrzennej Uniwersytetu Jagiellońskiego, Kraków. Koncepcja Przestrzennego Zagospodarowania Kraju 2030, Załącznik do uchwały nr 239 Rady Ministrów z dnia 13 grudnia 2011 r. (poz. 252).
Kwarciński T., Załoga E., 2019, Pasażerski transport regionalny, Wydawnictwo Naukowe PWN, Warszawa.

Małecka-Łyszczek M., 2013, Pojęcie i podziały zadań publicznych ze szczególnym uwzględnieniem zadań samorządu terytorialnego, Zeszyty Naukowe Uniwersytetu Ekonomicznego w Krakowie, 921(1), 55-69.

Rosik P., Pomianowski W., Goliszek S., Stępniak M., Kowalczyk K., Guzik R., Kołoś A., Komornicki T., 2017, Multimodalna dostępność transportem publicznym gmin w Polsce, Prace Geograficzne nr 258, IGiPZ PAN, Warszawa.

Rosik P., Pomianowski W., Guzik R., Goliszek S., Stępniak M., Komornicki T., 2018, Dostępność gmin transportem autobusowym, Prace Komisji Geografii Komunikacji Polskiego Towarzystwa Geograficznego, 21(1), 54-64.

Rydz E., 2006, Przemiany struktur społeczno-gospodarczych w okresie transformacji systemowej na Pomorzu Środkowym, Wydawnictwo Pomorskiej Akademii Pedagogicznej, Słupsk.

Sołtys J., 2013, Usługi publiczne jako czynnik miastotwórczy i wyznacznik rangi miasta w sieci osadniczej na przykładzie małych miast Polski Północnej, Acta Universitatis Lodziensis, Folia Geographica Socio-oeconomica 15(3), 3-19.

Taylor Z., 1999, Przestrzenna dostępność miejsc zatrudnienia, kształcenia i usług a codzienna ruchliwość ludności wiejskiej, Prace Geograficzne nr 171, Wydawnictwo Continuo, Warszawa.

Trammer K., 2019, Ostre cięcie. Jak niszczono polskq kolej, Wydawnictwo Krytyki Politycznej, Warszawa.

Trutkowski C. (red.), 2016, Realizacja usług publicznych w jednostkach samorzq̨du terytorialnego - ograniczenia, możliwości, rekomendacje, Fundacja Rozwoju Demokracji Lokalnej, Warszawa.

Wendt J., 2001, Geografia władzy w Polsce, Wydawnictwo Uniwersytetu Gdańskiego, Gdańsk.

Wskaźniki dostępności terytorialnej mieszkańców Polski do wybranych obiektów użyteczności publicznej, 2018, Centrum Badań i Edukacji Statystycznej GUS, Zakład Wydawnictw Statystycznych, Warszawa.

Żuber E., 2010, Województwo środkowopomorskie - dlaczego być powinno? Część l: Przesłanki historyczne i społeczne, ekonomiczne i prawne, Wydawnictwo Feniks, Koszalin. 